Meta

Journal des traducteurs

Translators' Journal

\title{
Stylistic Aspects in Arabic and English Translated Literary Texts: A Contrastive Study
}

\section{Hussein A. Obeidat}

Volume 43, numéro 3, septembre 1998

URI : https://id.erudit.org/iderudit/003753ar

DOI : https://doi.org/10.7202/003753ar

Aller au sommaire du numéro

Éditeur(s)

Les Presses de l'Université de Montréal

ISSN

0026-0452 (imprimé)

1492-1421 (numérique)

Découvrir la revue

Citer cet article

Obeidat, H. A. (1998). Stylistic Aspects in Arabic and English Translated Literary Texts: A Contrastive Study. Meta, 43(3), 462-467.

https://doi.org/10.7202/003753ar

\section{Résumé de l'article}

Dans cet article, l'auteur compare d'un point de vue stylistique des extraits de textes traduits de l'arabe à l'anglais et inversement. Chacun des extraits est analysé sur le plan lexical, syntaxique et textuel afin de dégager des règles généralisables dans le domaine de la traduction littéraire arabe/anglais. 


\section{BLOC-NOTES}

\section{STYLISTIC ASPECTS IN ARABIC AND ENGLISH TRANSLATED LITERARY TEXTS: A CONTRASTIVE STUDY}

Résumé

Dans cet article, l'auteur compare d'un point de vue stylistique des extraits de textes traduits de l'arabe à l'anglais et inversement. Chacun des extraits est analysé sur le plan lexical, syntaxique et textuel afin de dégager des règles généralisables dans le domaine de la traduction littéraire arabeanglais.

\footnotetext{
Abstract

The study aims at stylistically comparing selected excerpts of contemporary Arabic and English novels with their respective translations. A text of one thousand words in the source novel is randomly chosen, compared with the translated text and analysed in terms of lexical, syntactic and textual structure. The purpose is to identify and explain a number of general rules describing consistent patterns of stylistic change which occur during translation of literary work from Arabic to English and vice versa.
}

\section{INTRODUCTION}

Two notions are of relevance to the understanding of language difference: "Linguistic Relativism" which means that thinking is relative to the language learned and that speakers of different languages perceive the world differently, and the Chomskyan notion of "Linguistic Universals" according to which language is a universal phenomenon. By placing the focus on universal elements of language, one can reach a better understanding of the way language functions in general and the relationship between language and mind.

Although the two notions represent two different schools of linguistic thought and seem contradictory, they are not. In fact, the two converge into one basic assumption that language and thought are related. The two agree that structure of thought and language consist of both predictable universal elements as well as idiosyncratic ones. They simply emphasize different features in language.

The relativists emphasize the idiosyncratic elements of language and the universalists its general universal principles. The result is a difference in

Meta, XLIII, 3, 1998 approaches to the study of language and the subject matter on which it should focus.

The study of translation is based on implicit assumptions drawn from both the universalist and the relativist theories of language. The very nature of translation presupposes the existence of certain universal parameters which render all languages translatable. It also acknowledges that because of certain idiosyncratic elements in each language, a perfect tranlation is ultimately impossible.

According to Steiner (1975: 149):

The relativists' position carried to its logical conclusion holds that no complete acts of translation between different semantic fields are possible. That all translations are approximate and antologically reductive of meaning. The matrix of feeling and assocative context which energizes usage in any given tongue can be transferred into another idiom only partly and by virtue of periphrastic and metaphrastic manoeuvres which inevitably downgrade the intensity, the evocative means, and the formal autonomy of the original. Poets have often felt this.

A universal grammar will affirm the contrary, the intertranslatability of all languages. The fact that no closed speech has been found, none that native informants and foreign learners cannot comprehend and transfer, constitutes one of the strongest evidence in support of universalists.

The issue of equivalence is of novel importance in the study of translation in general and the translation of literary work in particular. Catford (1965) places special emphasis on the situational element in translation equivalence. He argues that both SL and TL texts must be relatable to the functionally relevant features of the situation to achieve translation equivalence. He also points to the concept of untranslatability of literary works. Catford believes that certain parts of a text are left untranslated because they are either untranslatable, or meant to give a local flavor to the translation.

Nida (1964) talks about the reproduction of the $\mathrm{SL}$ message by the closest equivalent in the TL, thus introducing Dynamic Equivalence or Functional Equivalence (Waard and Nida 1986) in translating. Consequently, preservation of the message rather than conversion of the form of the utterance is targeted in translating. 
Lefevere (1975) stresses the role of communicative value in literary translation. By this term he means the ability of the translator to measure the time-place-tradition elements found in both SL and TL.

The importance of the study of comparative translations stems from the fact that stylistic differences in the choice of lexis and grammatical categories constitute the difference between culture and thought. Literary translation presupposes commitment on the part of the translator to create the style of the author, thus consistent stylistic deviations from the source text must result from their linguistic differences and the differences which the translators have to account for.

\section{THE PRESENT STUDY}

This study aims to look into two literary texts randomly selected from two translated English and Arabic novels; The Thief and the Dogs by Najib Mahfouz and Great Expectations by Dickens.

The study compares the translation with the original text to highlight the differences in the stylistic choices of vocabulary and of grammatical categories between Arabic and English.

\section{METHOD}

From each novel a text of one thousand words in the source novel was randomly chosen, compared with the translated text, and analysed in terms of the following:

- Lexis;

- Syntax;

- Texual features.

A frequency count of lexical items between the source and the translated texts was done to account for the levels of abstraction and degrees of specificity and defintion. Moreover, a quantitative and qualitative analysis of grammatical categories in the source and the translated texts was done to account for their importance within sentences. At the textual level, differences between the ST and the TT are accounted for.

\subsection{Lexical Comparison}

Although English has lexical units for articles, for prepositions such as to, in, for personal pronouns, and for auxiliary verbs which mark tense and aspect, Arabic tends to incorporate these functions in nouns or verbs. Nevertheless, inflections for the above mentioned functions in the Arabic text were counted as independent lexical units with the exception of what constitute a gap in Arabic in particular structures; i.e., the copula in present/ timeless sentences, the indefinite article, and the implicit personal pronouns.

Apart from structural differences, the difference in the number of words between the Arabic and the English translations seems to suggest the existence of more significant differences in the distribution of vocabulary which can be attributed to differences in the style of prose writing in the two languages which is to a large extent governed by situations. See table $1 \& 2$ below.

\begin{tabular}{|l|c|c|}
\hline & Arabic & English \\
\hline Words & 1000 & 1585 \\
\hline Nouns & 308 & 430 \\
\hline Adjectives & 32 & 65 \\
\hline Sentences & 53 & 83 \\
\hline T-Units & 35 & 38 \\
\hline Simple Sentences & 18 & 45 \\
\hline Co-ordinates & 29 & 21 \\
\hline Complex & 4 & 9 \\
\hline Mixed & 2 & 8 \\
\hline Paragraphs & Arabic & English \\
\hline Levels of Abstraction & $134 / 308$ & $203 / 430$ \\
\hline $\begin{array}{l}\text { First-order entities: } \\
\text { Physical Object, e.g. } \\
\text { man, book, cat, etc. }\end{array}$ & $79 / 308$ & $107 / 430$ \\
\hline $\begin{array}{l}\text { Second-order entities: } \\
\text { Events, Process, etc. }\end{array}$ & $95 / 308$ & $120 / 430$ \\
\hline $\begin{array}{l}\text { Thrid-order entities: } \\
\text { Attitudes, Judgments, } \\
\text { Beliefs, etc. }\end{array}$ & & \\
\hline
\end{tabular}

Table 1

* The Thief and the Dogs

\begin{tabular}{|l|c|c|}
\hline & Arabic & English \\
\hline Words & 1000 & 900 \\
\hline Nouns & 163 & 181 \\
\hline Adjectives & 35 & 20 \\
\hline Sentences & 51 & 51 \\
\hline T-Units & 42 & 38 \\
\hline Simple Sentences & 9 & 13 \\
\hline Co-ordinates & 10 & 22 \\
\hline Complex & 14 & 8 \\
\hline Mixed & 18 & 8 \\
\hline Paragraphs & 18 & 14 \\
\hline Levels of Abstraction & Arabic & English \\
\hline First-order entities & 102 & 94 \\
\hline Second-order entities & 27 & 14 \\
\hline Thrid-order entities & 52 & 55 \\
\hline
\end{tabular}

Table 2

* Great Expectations

Though the Arabic texts have a greater number of nouns than the English text, fewer nouns in Arabic are modified (by other nouns or adjectives), and the English texts contain a greater number of adjectives than the Arabic texts. 
To analyze differences in the level of abstraction of the lexical items used in both the English and Arabic texts and their respective translations, the nouns have been divided into three categories: first, second, and third-order (Lyons 1977). The analysis shows that on average both the English source and translated texts have a higher proportion of first, second, and third-order entities than the Arabic source and translated texts.

\subsection{Syntactic Comparison}

The number of sentences shows difference only in the English transtated version of the Arabic text; i.e., The Thief and the Dogs, whereas the number of translated sentences in the English text into Arabic is the same. The number of T-units is higher in the English texts. Arabic texts clearly indicate the use of more co-ordinated sentences than the English texts which use more complex and mixed sentences (cf. table $1 \& 2$ above). This is in accordance with the claim that coordination is a salient feature of Arabic style and the fact that the punctuation system is used in Arabic in a non-functional manner (Williams 1984; Koch 1982, etc.)

\subsection{Textual Comparison}

The English translation of the Arabic text, unlike the Arabic translation of the English text, shows the frequent addition of information to the Arabic text especially with reference to cohesive devices.

\subsubsection{Personal reference}

Consider the following examples:

1. 'štarak-tu ma $a^{c} a-h u \overline{f i}(-) l(-)$ xidmati mund $u-l-$ tufulah.

Participate-1 I with-him in-def-service since -defchildhood

I worked with him since $m y$ childhood. (The Thief and the Dogs 186)

2. $Y a^{c} \overline{\mathrm{u}} d-\bar{u} n a$ wa hum yuxf- $\bar{u} n a-l-d u m \bar{u}^{c}$. return-they and they hide-they def tears They return drying their tears. (The Thief and the Dogs 186)

3. She was seated at her dressing table Kănat tajlisu 'ilatäwilat -l-tajmìl

Was sit to table -def-beauty (Great Expectations 121)

The utterances 1 and 2 above show that the pronouns $m y$ and their respectively are being added to the English translation of the Arabic ST. Whereas the pronoun her in the English utterance is being deleted in Arabic translation as shown in 3 above.

\subsubsection{Comparative Reference}

4. Wa kunta tu ibu-hu kamākunta ti ibu-l-šayxa wa akӨar.

And was like- him as was like-def oldman and more

You loved him even more than you loved. (The Thief and the Dogs 188)

5. It was quit in vain for me to... Lam 'ufli fi jaclihi yudrik...

did not succeed in make-him realize. (Great Expectations 123)

6. She would be quite familiar with me kānat amimah was intimate (Great Expectations 116)

Intensifiers such as even and quite are being added to the Arabic translation of the English ST or the English translation of the Arabic ST as shown in 4,5 , and 6 above.

\subsubsection{Thought connectors}

The use of additional thought connectors in the place of $w a$ (and) or, where no connector is used in Arabic is apparent in both texts. Consider the following example:

7. Wa li'ímāni-hi bi-lāh 'ic tanaq $-l-$ rid $\overline{\mathrm{a}}$, and for-believe -he in-God believed -def satisfaction, wa kana tullābu-hu yu ib-üna-hu and were students-his love-they-him He also believed in God, thus his students loved him (The Thief and the Dogs 186)

Addition of such cohesive markers to the English texts is a sign of preference for explicitness in English style. Lots of connectors such as thus, therefore, so, because, etc. were added to the English texts when in fact they are not present or implicit in the Arabic texts.

8. Wa bad $\bar{a}-l-m a k \bar{n}$ u kulluhu wa ka'nnama yá muruka bi-l- 'ibti ${ }^{c}$ a d lakinnaka kunta fimasis -lajati 'ila' 'is ${ }^{c}$ afin sari ${ }^{c}$, 'is ${ }^{c}$ afin $i^{c}$ sar.

The whole place seemed alain to you but you needed medical care, urgent care, for your mother. (The Theif and the Dogs 188)

The phrase "for your mother" is being added to the English text for explicitness; a clear case of managing. At the same time the repetition of the Arabic phrase "is ${ }^{c}$ afin sari ${ }^{c}$ " though functional in the Arabic text was deleted in the English text.

\subsubsection{Deletion}

Indirect speech phrases were deleted in the Arabic translation of the English ST. Also forms of address which are used in Arabic for respect were deleted in the English translation of the Arabic ST 
because they constitute a gap in the English language. Consider the following examples:

9. "pip" he said "I meant to say..."

"bib" gasad-tu -l-gawl

"pip" meant-I -def- say... (Great Expectations 124)

10. cam Mahran "al-rajul-l-tayyib

Mahran the good old man (The Thief and the

Dogs 125)

The word am in 10 above is left untranslated because it's equivalent in English (uncle) denotes blood relationship whereas in the Atabic text it is only a form of address.

\subsubsection{Addition of evaluative markers}

Markers of evaluativeness were added to the Arabic translations of the English ST as these markers are a common feature of Arabic. Consider the following examples:

11. I had to go to miss Havishame's room, and, after all, nothing was said about our fight... (Great Expectations 118).

innamā kāna calayya -l- dahāb 'ilāmanzil l- '́̄nisa Hafišam wa mac a $\underline{\text { da }}$ likfa 'inna šay'an lam yu skar $^{2}$ ${ }^{c}$ an qitälina...

12. The forge was shut up for the day, and we walked to town, and Joe and I... (Great Expectations 120)

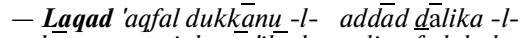
nahär wa - tajahanā 'ila-l- madina fádahabtu $m a^{c} \ldots$

Evaluative markers such as inna, laqad, etc. are frequently used as a stylistic feature of Arabic writing.

\subsubsection{Collocations}

Collocations depend on compatability of words. A coherent set of words relating to a particular topic or activity (especially in literary works) giving unity to a text. This doesn't mean that there are no incompatible collocations but they can be united via juxtaposition providing ironic contrast. The collocation in a sentence like The ship coursed the seas projects a physical image. Collocations in the Arabic text were erroneously translated and/or paraphrased rendering the text less effective. Consider the following examples:

13. Fanahạ̦at bil-mas '̄uliyyah fì sin mubakkirah

So you took responsibility at an early age.

14. You found your mother and yourself in a reception room by the entrance, a room more luxurious than you had ever seen before.

- Wajadta nafsak 'anta wa 'úmmuka fiq $\bar{a}^{c}$ atin faximatin lam tajrilaka fixayal

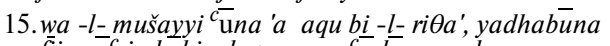
fijum $\bar{u}^{c}$ in bakiyah ømma ya ${ }^{c} \overline{\mathrm{u}} d \bar{u}$ na wa hum yujaffifuna $-l-$ dum $\bar{u}^{c}$

- But those who come with the bodies of the dead are really the ones who deserve pity more than they who go on weeping crowds and return drying their tears.
In 13 above the words took and responsibility do not collocate, hence an erroneous interpretation. The Arabic collocation "Lam tajri laka fi xayal" in 14 which literally means "did not run in your imagination" is paraphrased in English producing less effective translation. The English paraphrasing of the Arabic collocation in 15 above is not only less effective and lacks emotiveness but the whole utterance is grossly mistranslated.

Idioms can be considered as collocations since they consist of lexical items that are only idiomatic when they appear together. In translation one usually opts for functional equivalence to maintain effectiveness unless the idiom is culture bound and constitutes a gap in the target language. Consider the following example:

16. Wa-l-bolis hal yu jab bi hi!fatamtama sac id : wa la -l-siyàm fi rajab

- The police don't like anything! Sa'eed musmured "or anybody". (The Thief and the

\section{Dogs 189)}

The English translation of the Arabic text is no way near the intended meaning of the Arabic text let alone that the Arabic idiom "wa la -l-siyam $f i$ rajab" is not properly transtated.

\subsubsection{Repetition}

Repetition seems to be maintained in the translation of both the Arabic and the English text. Consider the following examples:

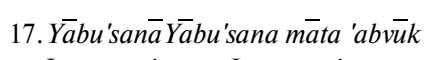

Its our misery... Its our misery your father died. (The Thief and the Dogs 188).

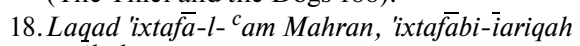
garibah

Old mahran disappeared. The man disappeared in mysterious way. (The Thief and the Dogs 188)

19. Break their hearts, my pride and hope, break their hearts.

Hattimiqulūbahum yā azizatiwa yá 'amali,

hasât -

Repetition in drama is functional for dramatization of situations, hence the maintaining of repetition in 17,18 and 19 above.

\subsubsection{Register}

Both texts the English and the Arabic maintain a high level of formality. The Arabic text uses a high level of standard Arabic.

\section{CONCLUSION}

Research in the area of contrastive stylistics of Arabic and English literary works though very important to enhance our understanding of thought patterns of speakers of both languages and enrich our cultural heritage, is very scarce. In depth investi- 
gations in this area are of novel importance so as to confirm generalization about similarities and differences in the structure of discourse and style of the two languages.

The comparison made in this study have shown that each text and its translation seem to generate more or less comparable proportions of entities on the three levels of abstraction. This is in accordance with Nida's $(1966,1983)$ claim that the general proportion of specific to generic vocabulary is comparable in all human languages.

At the syntactic level English seems to use more complex T-units aiming at a higher level of complexity; whereas Arabic tends to rely on co-ordinated T-units as a stylistic character of its prose writing style.

English on the textual level uses more explicit connectors inter- and intrasententially compared to implicit connectors and more evaluativeness favored by Arabic style of prose writing.

Finally, discoursal problems/errors and misinterpretation of units of discourse at all levels; sentence, paragraph, texts, which are not dealt with in this paper, constitute a very rich area for research. The role cultural factors play in constructing and interpreting discourse at all levels is also an area researches might find interesting to be investigated.

HUSSEIN A. OBEIDAT Language Center, Yarmouk University, Yarmouk, Jordan

\section{REFERENCES}

CATFORD, J.C. (1965): A Linguistic Theory of Translation, London, Oxford University Press.

DICKENS, Charles (1982): Great Expectations, Edited by James Gebson published by Macmillan Education Ltd., London, Translated into Arabic by Dar Al-Hilal Library, Beirut 1986.

ENKVIST, Nils Erik (1991): "On the Interpretability of Texts in General and of Literary Texts in Particular", Roger Sell (Ed.), Literary Pragmatics, London, Routledge.

KAPLAN, Robert (1966): "Cultural Thought patterns in Inter-cultural Education", Language Learning, Vol. $16(1,2)$ pp. 1-21.

KAPLAN, Robert (1982): "Contrastive Rhetoric Revisited", Paper read at the 1982 TESOL conference, Honolulu.

KOCK, Barbara (1982): "Presentation as Proof: the Language of Arabic Rhetoric", Anthropological Linguistic, 25 (1), pp. 47-57.

LEFEVERE, André (1975): Translating Poetry, The Netherlands, Assen, Vancorcum.

LYONS, John (1977): Semantics, London, Cambridge University Press.

MAHFOUZ, Naguib (1973): The Thief and the Dogs, Published by Dar al-qalam, Beirut,
Translated by Adel Ata Elyas, Dar Al-Shoroug, Jeddah 1987.

NIDA, Eugene A. et al. (1983): Style and Discourse, Published by the Bible Society of America.

NIDA, Eugene A. and Charles TABER (1982): The Theory and Practice of Translation, Leiden, E.J. Brill.

NIDA, Eugene A. (1964): Towards a Science of Translating, Leiden, E.J. Brill.

STEINER, George (1975): After Babel: Aspects of Language and Translation, London, Oxford University Press.

TURNER, G. W. (1973): Stylistics, England, Penguin Books.

VAN DIJK, Teun (1977): Text and Context: Explorations in the Semantics and Pragmatics of Discourse, London, Longman.

WAARD, Jan de \& Eugene A. NIDA (1986): From one Language to Another, Nashville (Tennessee), Thomas Nelson Inc.

WILLIAMS, Michael (1984): "A problem of cohesion", John Swales and Hasan Mustafa (Eds), ESP in the Arab World, Birmingham, University of Aston, pp. 118-129.

ZELLERMAYER, Michael (1984): Hebrew and English: Stylistic Aspects of Perspective Translations, Ph.D. dissertation New York University. 